\title{
Robert Rollinger. « Von Kyros bis Xerxes: Babylon in persischer Zeit und die Frage der Bewertung des herodoteischen Geschichtswerkes - eine Nachlese »
}

\section{Astrid Nunn}

\section{OpenEdition} Journals

Édition électronique

URL : http://journals.openedition.org/abstractairanica/42619

DOI : 10.4000/abstractairanica.42619

ISBN : 1961-960X

ISSN : 1961-960X

Éditeur :

CNRS (UMR 7528 Mondes iraniens et indiens), Éditions de l'IFRI

\section{Référence électronique}

Astrid Nunn, « Robert Rollinger. « Von Kyros bis Xerxes: Babylon in persischer Zeit und die Frage der Bewertung des herodoteischen Geschichtswerkes - eine Nachlese » », Abstracta Iranica [En ligne], Volume 37-38-39 | 2018, document 23, mis en ligne le 10 mars 2018, consulté le 27 septembre 2020 URL : http://journals.openedition.org/abstractairanica/42619; DOI : https://doi.org/10.4000/ abstractairanica.42619

Ce document a été généré automatiquement le 27 septembre 2020.

Tous droits réservés 


\title{
Robert Rollinger. « Von Kyros bis Xerxes: Babylon in persischer Zeit und die Frage der Bewertung des herodoteischen Geschichtswerkes - eine Nachlese »
}

\author{
Astrid Nunn
}

\section{RÉFÉRENCE}

Robert Rollinger. «Von Kyros bis Xerxes: Babylon in persischer Zeit und die Frage der Bewertung des herodoteischen Geschichtswerkes - eine Nachlese ", in M. Krebernik, H. Neumann (éds.), Babylonien und seine Nachbarn in neu- und spätbabylonischer Zeit. Wissenschaftliches Kolloquium aus Anlass des 75. Geburtstags von Joachim Oelsner, Jena, 2. und 3. März 2007, (AOAT 369), 2014, Münster, p. 147-194.

1 Robert Rollinger. « Von Kyros bis Xerxes: Babylon in persischer Zeit und die Frage der Bewertung des herodoteischen Geschichtswerkes - eine Nachlese», in M. Krebernik, H. Neumann (éds.), Babylonien und seine Nachbarn in neu- und spätbabylonischer Zeit. Wissenschaftliches Kolloquium aus Anlass des 75. Geburtstags von Joachim Oelsner, Jena, 2. und 3. März 2007, (AOAT 369), 2014, Münster, p. 147-194.

2 Hérodote est-il le "père de l'histoire » ou ne l'est-il pas ? L'A. ne traite que le seul cas d'Hérodote en Babylonie. Il passe en revue les diverses opinions exprimées à ce sujet, tout en essayant de reconstituer la Babylone qu'Hérodote aurait vue. D'autre part il semble à l'A. que la valeur historique du récit d'Hérodote n'est acceptée que si Hérodote a visité Babylone personnellement. Dans le cas d'une réponse positive, certains scientifiques ne se donnent plus la peine de remettre en cause Hérodote, qui en tant que grec, ne peut que représenter une source sérieuse. L'A. s'en prend finalement à 
notre historiographie, dans laquelle les Grecs sont crédibles et les sources « étrangères » non grecques susceptibles d'être exagérées, mensongères ou rêvées.

\section{AUTEURS}

\section{ASTRID NUNN}

Université de Munich 